\title{
Template Khusus Untuk Menulis Notasi Angka: Modifikasi Fungsi Tools Program Aplikasi Musik Finale
}

\author{
Branckly Egbert Picanussa \\ Fakultas Seni Keagamaan Kristen, Program Studi Musik Gereja, Institut Agama Kristen Negeri, Ambon, Indonesia \\ E-mail: brancklyegbert@gmail.com
}

Submitted 19-01-2020; Accepted 09-02-2020; Published 15-02-2020

\begin{abstract}
Abstrak
Notasi angka merupakan salah satu notasi musik yang sangat populer kepada kebanyakan masyarakat Indonesia, khususnya para penggubah musik dan praktisi musik yang tidak belajar musik melalui pendidikan formal. Artikel ini merupakan salah satu penelitian tentang modifikasi tools dari program aplikasi musik Finale untuk mendapatkan template khusus untuk menulis notasi angka. Metode yang digunakan adalah penelitian tindakan. Dengan metode tersebut, peneliti menggunakan tools yang ada pada program aplikasi musik Finale untuk mendapatkan template khusus untuk menolis notasi angka. Hasil yang diperoleh adalah sebuah template untuk menulis notasi angka.
\end{abstract}

Kata Kunci: Notasi angka, Program Aplikasi Musik Finale.

\begin{abstract}
The numerical notation is one of musical notation which is very popular for most of the Indonesian people, especially composers or music practitioners who have not learned music in formal education. This article is one of the researches about tools modification of music application program of Finale to get a special template to write numerical notation. The method which is used in this research is action research. With this method, the researcher use Finale Music Program tools to get a special template to write numerical notation. The result of this research is a special template to write numerical notation.
\end{abstract}

Keywords: Numerical Notation, Finale Music Application Program.

\section{PENDAHULUAN}

Kemajuan ilmu pengetahuan, teknologi, dan seni (IPTEKS) telah berdampak pada digunakannya komputer dalam berbagai bidang kehidupan manusia, termasuk di dalamnya musik. Sejalan dengan kemajuan IPTEKS telah dikembangkan berbagai program aplikasi untuk menulis dan mendengar notasi musik. Sayangnya, program-program yang dikembangkan hanya dapat dipergunakan oleh para penggiat musik notasi balok. Sementara para penggiat musik notasi angka masih pada penggunaan huruf yang dimodifikasi khusus untuk penulisan notasi angka atau hanya menulis secara manual karyanya, dan belum dapat mendengarkan karya yang telah ditulisnya.

Sebagaimana telah dikemukakan di atas, terdapat beragam program yang dibuat khusus untuk menulis dan mendengar notasi balok. Satu di antaranya adalah Program Aplikasi Musik Finale. Menarik bahwa Finale memberikan kemungkinan bagi kita untuk membuat sebuah template untuk kebutuhan tertentu. Pertanyaannya, mungkinkah dibuat suatu template Finale yang dikhususkan untuk menulis, mendengar, dan mencetak notasi angka?

Tidak dapat disangkal bahwa sampai saat ini notasi angka merupakan salah satu cara penulisan musik yang sangat familiar untuk para penggiat musik di Indonesia, termasuk di dalamnya para komposer dan arrengger musik yang selama ini menulis karyanya dalam bentuk notasi angka. Sehubungan dengan hal tersebut, pertanyaan yang sangat penting untuk dikemukakan sehubungan dengan hal tersebut adalah mungkinkah dikembangkan suatu template Finale yang dapat menolong para penggiat notasi angka untuk, bukan hanya menulis dan mencetak karyanya, tetapi juga mendengar atau menggubah karya musiknya secara langsung? Jika hal tersebut memungkinkan, bagaimana menggunakan template tersebut?

Tulisan ini memberikan informasi tentang hasil penelitian yang dilakukan oleh penulis. Penelitian ini bertujuan untuk menghasilkan sebuah template Finale khusus untuk menulis notasi angka satu suara. Manfaat dari penelitian ini adalah menolong para penggiat notasi angka untuk menulis karya musik yang mereka buat. Penelitian ini sangat diperlukan untuk menghasilkan sebuah template Finale bagi para penggiat notasi angka yang memudahkan mereka untuk menotasikan karya mereka. Karya yang dinotasikan bukan hanya tertulis, tetapi juga dapat didengar dan dimodifikasi sesuai dengan kreativitas penggiat notasi angka dalam menghasilkan suatu karya musikal, dalam hal ini satu suara.

Penelitian ini lebih difokuskan pada pembuatan sebuah template untuk menulis notasi angka. Pembuatan template tersebut dilakukan dengan memodifikasi beberapa default tools Program Aplikasi Finale. Template yang dihasilkan akan digunakan untuk menulis notasi angka dengan cara copy-paste. Notasi yang telah dituliskan dapat didengar dan/atau dimodifikasi, dan dicetak untuk digunakan oleh para penggiat musik vokal.

\section{METODE PENELITIAN}

Penelitian tentang template khusus untuk menulis notasi angka menggunakan metode penelitian tindakan (Tampubolon, 2014; Sukardi, 2013). Berbagai tindakan akan dilakukan - secara berulang - terhadap tools bawaan Program Aplikasi Musik Finale hingga diperoleh suatu format yang dapat digunakan untuk menulis notasi angka - dan dapat juga mendengar notasi angka yang telah ditulis.

Pelaksanaan tindakan dalam penelitian ini akan dilakukan dengan prosedur berulang, sebagaimana terlihat pada gambar berikut ini (bnd. Tampubolon, 2014; Sukardi, 2013). 


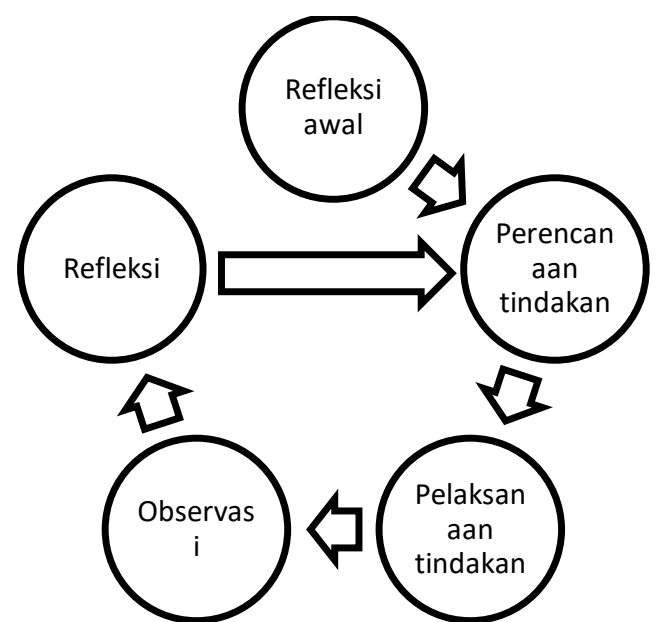

Gambar 1. Pelaksanaan tindakan - prosedur berulang

Refleksi awal yang dimaksudkan berhubungan dengan objek atau komponen notasi angka yang hendak diperoleh dari kegiatan modifikasi tools bawaan Finale. Selanjutnya direncanakan tindakan untuk memperoleh format penulisan notasi angka yang dikehendaki. Kemudian rencana tindakan dibuat terhadap tools bawaan Finale, diamati apakah telah sesuai dengan perencanaan yang dibuat. Berdasarkan pada pengamatan tersebut, dilakukanlah refleksi untuk melanjutkan atau tidak melanjutkan tindakan (bnd. Tampubolon, 2014; Sukardi, 2013).

Data dari penelitian ini diperoleh melalui observasi dan dokumentasi terhadap Program Aplikasi Musik Finale dan format penulisan notasi angka. Data-data tersebut dianalisis untuk kemudian dikelompokkan ke dalam komponen-komponen yang perlu diberikan tindakan khusus untuk memperoleh atau mengahsilkan sebuah template Finale khusus yang dapat digunakan untuk menulis - dan mendengar - notasi angka.

\section{ANALISIS DAN PEMBAHASAN}

Penelitian tentang template khusus untuk menulis notasi angka dengan menggunakan Program Aplikasi Musik Finale, sepengetahuan penulis, belum pernah ada. Akan tetapi, beberapa hal yang berkaitan dengan usaha mengembangkan penulisan notasi angka telah dilakukan.

Seiring dengan perkembangan ilmu pengetahuan dan teknologi, khususnya di bidang komputer dan program aplikasi komputer telah dikembangkan juga program khusus untuk menulis notasi angka. Hanya saja, perlu dilakukan modifikasi sehingga program tersebut menjadi lebih dikenal oleh para komposer notasi angka. Juned Junaedi menginformasikan,

S-Music adalah program notasi angka gratis produksi A1 Soft. Program ini merupakan notasi angka yang pertama ada dari software notasi angka sejenis. ... Software ini dibuat dengan tujuan untuk membantu mempermudah menulis musik dengan notasi angka dan berbagai simbol musik khusus lainnya. Selain itu, anda juga dapat menyimpan dan mencetak hasil tulisan notasi angka tersebut." [3]

Tentang program S-Music, Junaedi berpendapat juga bahwa software ini masih perlu diperbarui bila hendak digunakan di Indonesia karena memiliki sedikit perbedaan penulisan, khususnya letak bendera, dengan model notasi angka yang berkembang di Indonesia. Perbedaan tersebut dapat dilihat pada gambar di bawah ini [3].

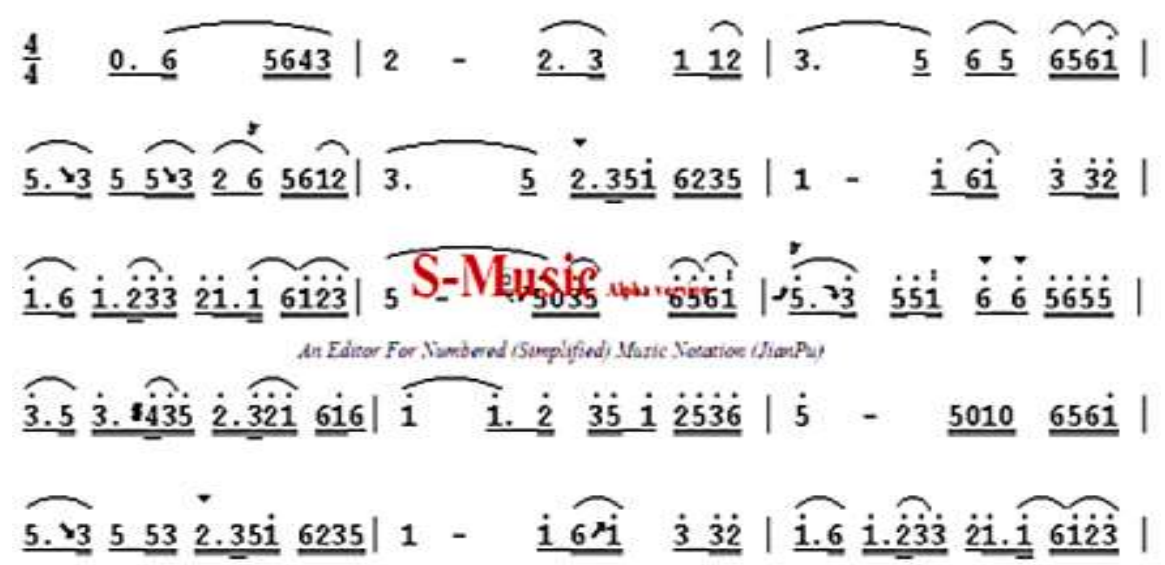

Gambar 2. Partitur yang ditulis dengan program S-Music 
Upaya untuk mengembangkan penulisan notasi angka dengan menggunakan komputer telah dilakukan juga oleh Joas Adiprasetya dengan membuat huruf khusus yang dapat digunakan pada beberapa program pengolahan kata, misalnya Microsoft Word, sebagaimana terlihat pada gambar berikut ini [4]

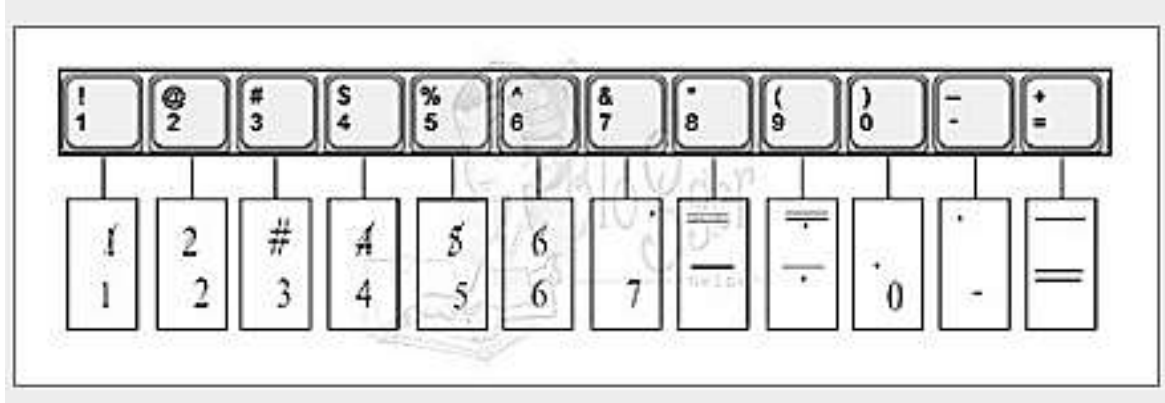

Gambar 3. Huruf Khusus Notasi Angka Joas Adiprasetya

Sebenarnya, masih ada kemungkinan lain yang bukan hanya menulis notasi angka, tetapi juga dapat mendengar notasi angka yang telah ditulis dengan tampilan yang lebih dikenal di Indonesia. Kemungkinan lain tersebut dapat dilakukan dengan membuat template khusus dengan jalan memodifikasi beberapa tools bawaan Program Aplikasi Musik Finale.

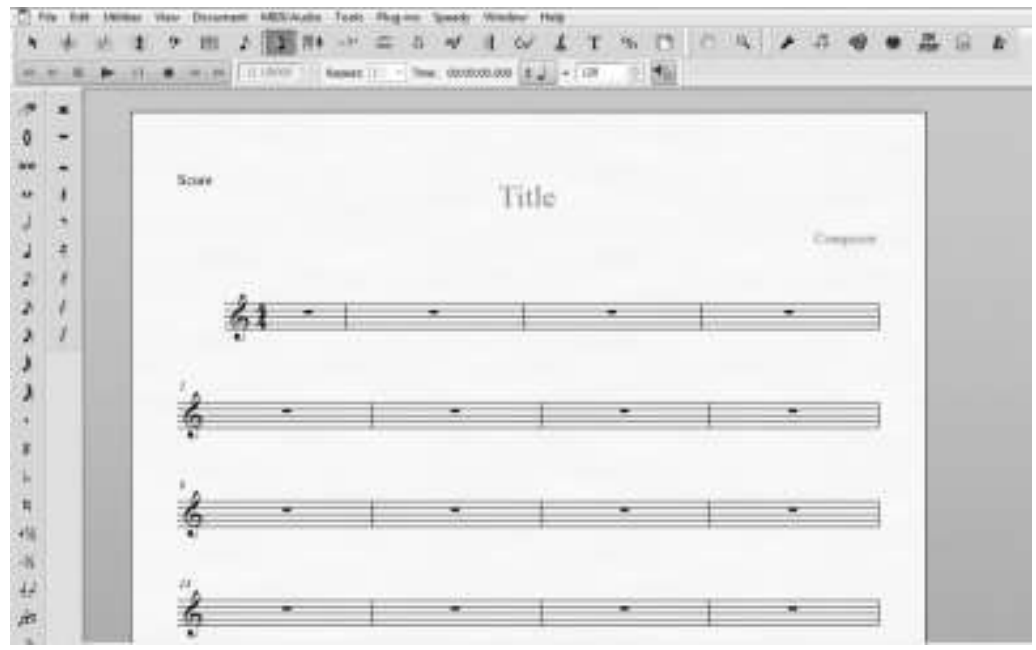

Gambar 4. Default Worksheet Finale 2014

Pertanyaannya adalah tools apa saja yang perlu dimodifikasi dan bagaimana modifikasi dilakukan sehingga diperolah suatu template dengan format tertentu yang dapat digunakan untuk menulis notas angka. Sehubungan dengan format penulisan notasi angka, salah satu di antaranya sebagaimana terlihat pada gambar berikut ini [5].

168a. HAI DUNIA, LIHAT TUHAN

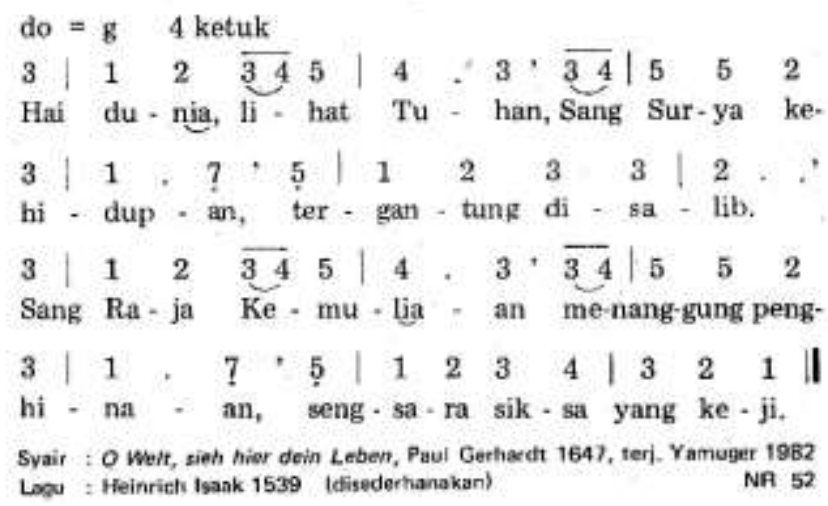

Gambar 5. Salah satu format penulisan notasi angka

Notasi angka merupakan salah satu sistem penulisan musik yang sangat dikenal di Indonesia, termasuk di dalamnya para komposer lokal (daerah) di Indonesia. Notasi angka, sebenarnya, telah lama dikembangkan. Yayasan Musik Gereja (YAMUGER) di Indenesia, dalam Kidung Jemaat Empat Suara, mengemukakan "Notasi lagu dengan not angka diprakarsai 
oleh ahli pendidikan Jean Jacques Rousseau (1712-1778), kemudian dikembangkan oleh Pierre Galin (1886-1821) dan Aime Paris (1798-1866) dan akhirnya disempurnakan oleh Emile J.M. Cheve (1804-1864) [6].

Sebagaimana notasi balok, di dalam notasi angka terdapat juga berbagai unsur musik. Musik memiliki beberapa unsur. Menurut Joseph Machlis dan Kristine Forney, unsur-unsur yang membentuk musik adalah: (1) melodi, (2) ritme, (3) harmoni, (4) tekstur, (5) bentuk, (6) tempo, dan (7) dinamika [7]. Sementara menurut William Duckworth dan Edward Brown berpendapat bahwa musik memiliki tujuh unsur: (1) bunyi, (2) ritme dan birama, (3) melodi (sumber dan manipulasi nada), (4) harmoni, (5) tekstur, (6) timbre, dan (7) bentuk atau struktur [8].

Bagi Joseph Kerman, unsur musik yang paling mendasar adalah: (1) nada (pitch), (2) dinamika (dynamics), (3) warna suara (tone color), (4) tangga nada (scale), (5) ritme (rhythm), (6) tempo (tempo), serta (7) nada dan waktu (pitch and time) yang terbentuk dalam melodi, harmoni, dan kontrapung. Unsur musik yang lain, menurut Kerman adalah Struktur yang di dalamnya ada melodi, tekstur, kunci dan modus, serta bentuk dan gaya [9].

Sementara menurut Roger Kamien, musik memiliki beberapa unsur, yakni: (1) bunyi yang terdiri dari tiga komponen (nada, dinamika, dan warna suara), (2) media pertunjukan yang terdiri dari suara dan alat-alat musik, (3) ritme yang terdiri dari ketukan, birama, aksen dan sikopasi, serta tempo, (4) notasi musik yang terdiri dari notasi nada, notasi ritme, notasi diam, tanda birama, dan score, (5) melodi, (6) harmoni, (7) kunci atau tangga nada, (8) tekstur, (9) bentuk, (10) pertunjukan, dan (11) gaya musik [10].

Berdasarkan pada keempat pendapat tersebut dapat dikatakan bahwa musik memiliki unsur bunyi dan diam, beragam pola dan kecepatan ritme, melodi, harmoni, bentuk atau struktur, dinamika, dan warna suara. Ritme dalam musik dapat diartikan sebagai panjang-pendeknya suatu bunyi dan/atau diam yang tersusun dalam satu atau beberapa ruas birama dengan pola, birama, dan kecepatan tertentu (Kamien, 1992; Duckworth, William, 1978; Machlis, Joseph, 1999). Melodi dapat diartikan sebagai rangkaian nada-nada tunggal dalam beragam pola dan kecepatan ritme yang tertata dalam bentuk atau struktur, dengan atau tanpa dinamika untuk dinyanyikan atau dimainkan oleh warna suara tertentu (Kamien, 1992; Duckworth, William, 1978; Machlis, Joseph, 1999). Harmoni adalah susunan vertikal dua nada atau lebih dengan interval (jarak antar nada) dan ritme tertentu yang ditata dalam suatu tangga. (Kamien, 1992; Duckworth, William, 1978; Machlis, Joseph, 1999; Kermen, 1987).

Selain ketiga unsur di atas, musik juga memiliki unsur bentuk, yakni suatu struktur atau kerangka pengembangan suatu komposisi musikal (Kamien, 1992; Duckworth, William, 1978; Machlis, Joseph, 1999). Menurut Joseph Machlis dan Kristine Forney, dalam bentuk terdapat dua komponen utama, yakni pengulangan dan kontras. Penataan kedua hal tersebut dapat menghasilkan bentuk yang sama atau hampir sama dan bisa juga bervariasi. Di dalam musik terdapat beragam bentuk. Dua di antaranya adalah binary form dan trenary form atau bentuk dua bagian dan tiga bagian. Musik memiliki bentuk binary (A-B) bila musik memiliki struktur satu statement (A) dan satu departure (B). Sementara suatu musik dikatakan berbentuk trenary bila musik memiliki terjadi perluasan ide dari statement dan departure kemudian kembali ke bagian yang pertama. (Machlis, Joseph, 1999; Kamien, 1992; Duckworth, William, 1978).

Musik juga memiliki unsur tempo atau kecepatan. Tempo dalam musik adalah kecepatan suatu ketukan (bunyi atau diam) (Kamien, 1992; Kermen, 1987). Menarik bahwa menurut Joseph Machlis dan Kristine Forney, tempo dari suatu musik memiliki implikasi terhadap emosi (Machlis, Forney, 1999). Dengan kata lain, tempo dari suatu musik dapat mempengaruhi emosi manusia yang mendengar atau yang memainkan musik. Musik dengan tempo yang cepat cenderung memberikan semangat, gembira, ceria, dan riang. Sementara musik dengan tempo yang lambat cenderung membawa suasana emosional ketenangan dan ada juga yang sedih.

Unsur musik yang menandakan volume atau tingkatan keras lembut suatu musik dimainkan atau dinyanyikan (Machlis, Joseph, 1999; Kamien, 1992). Dinamika dalam musik dapat ditandai dengan huruf yang memiliki arti tertentu yakni $p$ (piano: lembut), mp (mezzopiano: agak lembut), pp (pianissimo: sangat lembut), mf (mezzoforte: agak keras), $f($ forte: keras), dan ff (fortissimo: sangat keras). Selain itu, ada juga dinamika yang bergerak secara teratur atau perlahan-lahan berubah. Dinamika jenis ini biasanya dalam bentuk tulisan atau gambar. Dalam bentuk tulisan misalnya cresc. atau crescendo (berangsur-angsur keras) dan decresc. atau decrescendo atau dim. atau diminuendo (berangsur-angsur lembut). Sementara dalam bentuk gambar, sebagaimana terlihat pada gambar berikut ini (Machlis, Joseph, 1999; Kamien, 1992; Kermen, 1987).

cresc. atau crescendo

decresc. atau decrescendo atau dim. atau

\section{diminuendo}

Gambar 6. Crescendo dan Decrescendo

Warna suara (timbre atau tone color) dalam musik dapat diartikan sebagai karakter dan kualitas bunyi yang dihasilkan oleh suara manusia atau alat-alat musik tertentu (Kermen, 1987; Kamien, 1992). Khusus untuk suara manusia, dapat dikelompokkan menjadi suara perempuan (Soprano, Mezzo-Soprano, Alto) dan suara laki-laki (Tenor, Baritone, Bass) (Machlis, Joseph, 1999, Kamien, 1992). 


\section{IMPLEMENTASI}

Mengingat penelitian ini difokuskan pada pembuatan template Finale untuk menulis notasi angka yang dapat digunakan oleh para komposer, penggiat notasi angka, untuk menulis karya musikal (nyanyian) satu suara dan memerhatikan format penulisan notasi angka, sebagaimana telah dikemukakan sebelumnya, maka pembuatan template Finale khusus untuk menulis notasi angka berubungan dengan beberapa komponen: (1) judul - dan subjudul (jika ada), (2) penotasian (nada dasar, tanda birama, ritme, melodi, dinamika, tempo, dan warna suara), dan (3) Lirik atau syair.

Sebagaimana telah dikemukakan di atas, data-data yang berhubungan langsung dengan program aplikasi musik finale 2014 diperoleh langsung dari program aplikasi finale. Data-data yang diperoleh kemudian dianalisis untuk selanjutnya merencanakan tindakan khusus untuk memperoleh template yang diinginkan dengan prosedur berulang (Gb. 1).

Telah dikemukakan juga pada bagian metodologi penelitian bahwa refleksi awal yang dimaksudkan berhubungan dengan objek atau komponen notasi angka yang hendak diperoleh dari kegiatan modifikasi tools bawaan Finale. Selanjutnya direncanakan tindakan untuk memperoleh format penulisan notasi angka yang dikehendaki. Kemudian rencana tindakan dibuat terhadap tools bawaan Finale, diamati apakah telah sesuai dengan perencanaan yang dibuat. Berdasarkan pada pengamatan tersebut, dilakukanlah refleksi untuk melanjutkan atau tidak melanjutkan tindakan.

Berdasarkan pada refleksi yang dilakukan terhadap berbagai modifikasi tools yang terdapat di dalam program aplikasi musik Finale, dapatlah dikatakan bahwa FiTem_BEP telah selesai dibuat dan telah dapat digunakan untuk menulis notasi angka untuk satu suara.

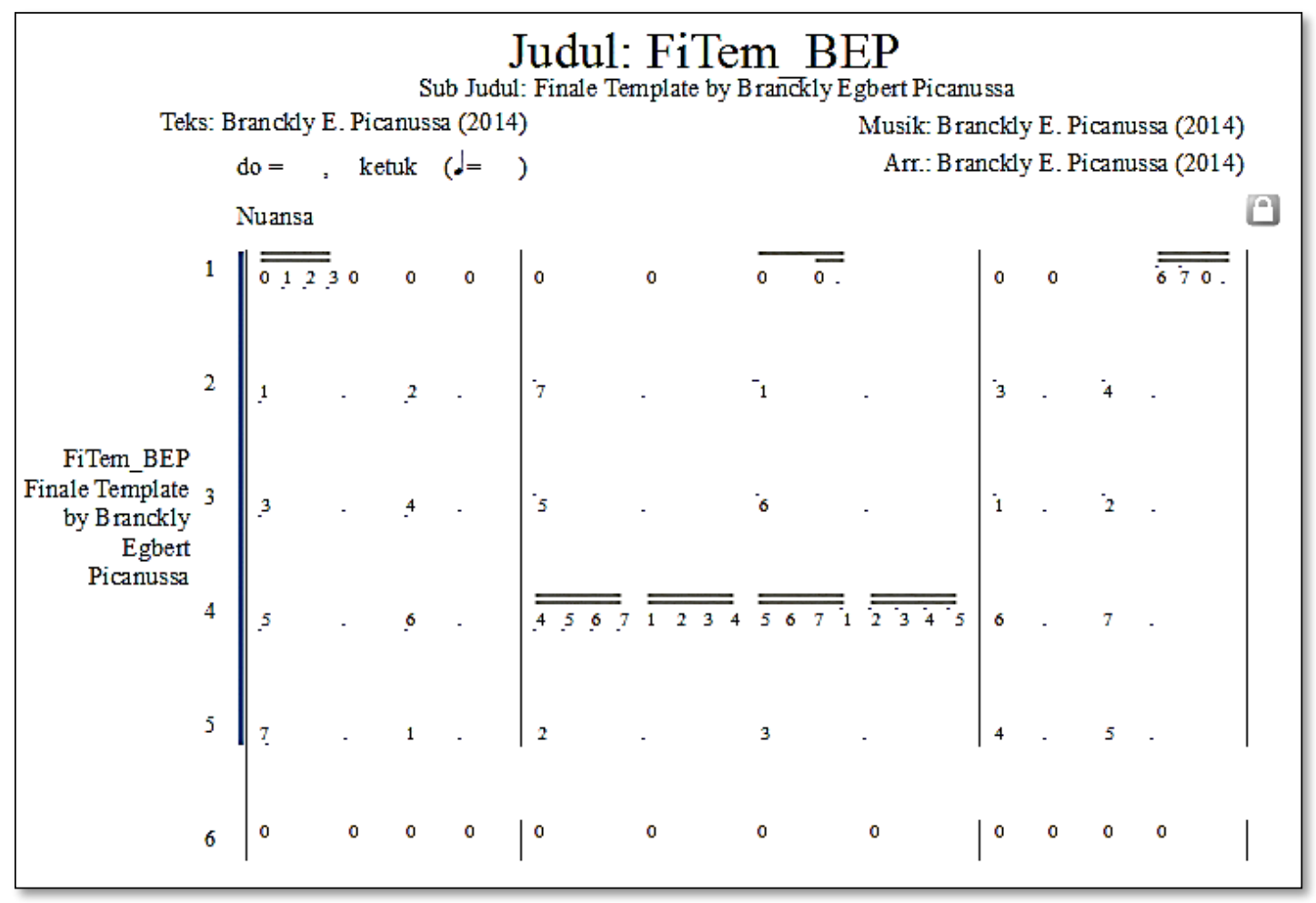

Gambar 7. Tampilan Akhir FITEMBEP

\section{KESIMPULAN}

Berdasarkan pada penelitian yang dilakukan dapatlah disimpulkan bahwa dengan melakukan tindakan-tindakan tertentu terhadap berbagai tools yang terdapat pada program aplikasi musik Finale dapat dimodifikasi sebuah template Finale khusus untuk menulis notasi angka, yang oleh peneliti disebut FITEMBEP atau Finale Template by Branckly Egbert Picanussa. Selain dapat menulis notasi angka, penulisan notasi dengan template tersebut dapat juga didengar. Semoga hasil penelitian ini dapat menolong para penggiat notasi angka untuk menulis karya musik mereka.

\section{REFERENCES}

[1] S. Tampubolon, Penelitian Tindakan kelas sebagai Pengembangan Profesi Pendidik dan Keilmuan. Jakarta: Penerbit Erlangga, 2014.

[2] Sukardi, Metode Penelitian Pendidikan Tindakan Kelas: Implementasi dan Pengembangannya. Jakarta: Bumi Aksara, 2013.

[3] djuned, "s-music-software-notasi-angka," http://www.djuned.com, 2012. [Online]. Available: http://www.djuned.com/2012/07/s-music-softwarenotasi-angka.html?q=S-Music+Software+Notasi+Angka. [Accessed: 10-Jan-2020].

[4] henriyulianto, "font-notangka2-by-joas-adiprasetya," henriyulianto.wordpress.com, 2007.

[5] YAMUGER, Ed., Kidung Jemaat Besar Ekonomis, 2nd ed. Jakarta: YAMUGER, 2010.

[6] -----------, Ed., Kidung Jemaat Empat Suara. Jakarta: YAMUGER, 2011.

[7] Joseph Machlis and Kristine Forney, The Enjoyment of Music, 8th ed. New York: W.W. Norton \& Company, 1999. 
JURIKOM (Jurnal Riset Komputer), Vol. 7 No. 1, Februari 2020 e-ISSN 2715-7393 (Media Online), p-ISSN 2407-389X (Media Cetak)

DOI 10.3086/jurikom.v7i1.1756

Hal 50-55

[8] William Ducworth and Edward Brown, Theoretical Foundations of Music. Belmont: Wadsworth Publishing Company Inc, 1978.

[9] J. Kermen, Listen: Brief Edition. New York: Worth Publishers Inc, 1987.

[10] R. Kamien, Music: An Appreciation, 5th ed. New York: McGraw-Hill Inc, 1992. 